\title{
SIMPLIFIED SCOBEY FORMULA FOR DETERMINING HEAD LOSS IN PRESSURIZED PIPES
}

\author{
FÓRMULA SIMPLIFICADA DE SCOBEY PARA A DETERMINAÇÃO DA PERDA DE \\ CARGA EM TUBULAÇÕES PRESSURIZADAS
}

\author{
Juciano Gabriel da Silva ${ }^{1}$, Marcia Xavier Peiter ${ }^{2} \oplus$, Adroaldo Dias Robaina ${ }^{3}$, Jhosefe \\ Bruning $^{4} \oplus$, Miguel Chaiben Neto ${ }^{5}$, Laura Dias Ferreira ${ }^{6} \odot$
}

\footnotetext{
${ }^{1}$ Engenheiro Agrônomo, Mestrando em Engenharia Agrícola, Dept. Eng. Rural, UFSM, Santa Maria, RS, Brasil

${ }^{2}$ Doutora em Engenharia Civil, professora associada da UFSM, Santa Maria, RS, Brasil

${ }^{3}$ Doutor em Engenharia Civil, professor titular da UFSM, Santa Maria, RS, Brasil

${ }^{4}$ Doutorando em Engenharia Agrícola, Dept. Eng. Rural, UFSM, Santa Maria, RS, Brasil

${ }^{5}$ Doutorando em Engenharia Agrícola, Dept. Eng. Rural, UFSM, Santa Maria, RS, Brasil

${ }^{6}$ Doutoranda em Engenharia Agrícola, Dept. Eng. Rural, UFSM, Santa Maria, RS, Brasil
}

\begin{abstract}
Head loss in pressurized pipelines is one of the factors that must be considered in the hydraulic design. Therefore, the objective of this work was to simplify Scobey's empirical equation to calculate head loss in Polyvinyl Chloride pipes with nominal diameters from 32 to 200 millimeters and compare it with the Darcy-Weisbach equation. The performance of the simplified equation was statistically evaluated using the Willmott's index of agreement, correlation coefficient, performance index and percentage error. The simplified formula showed better correlation than the original equation, excellent performance index, and percentage errors smaller than $6 \%$ in most simulations compared to the results obtained by the DarcyWeisbach equation.
\end{abstract}

Keywords: Darcy-Weisbach, empirical equation, plastic pipes.

RESUMO: A perda de carga em tubulações pressurizadas é um dos fatores que devem ser considerados no momento do dimensionamento hidráulico. Portanto, o objetivo do trabalho foi simplificar a equação empírica de Scobey, para o cálculo da perda de carga em tubos de Policloreto de Vinila com diâmetros nominais de 32 a 200 milímetros e comparar com a equação de Darcy-Weisbach. O desempenho da equação simplificada foi avaliado estatisticamente através do índice de concordância de Willmott, coeficiente de correlação, índice de desempenho e o erro percentual. A fórmula simplificada apresentou melhor correlação do que a equação original, excelente índice de desempenho, além de erros percentuais menores que $6 \%$ na maioria das simulações em comparação com os resultados obtidos pela equação de Darcy-Weisbach.

Palavras-chave: Darcy-Weisbach, equações empíricas, tubos plásticos. 


\section{INTRODUCTION}

In the hydraulic design of irrigation systems, it is essential to know the energy losses, which occur from the motor-pump set to the end of the irrigation system. Head loss is one of the specific variables during the design process (ALVES et al., 2017), being directly related to the cost of pipes, choice of the motor-pump set and energy consumption (MIRANDA et al., 2019).

Continuous head loss in irrigation systems occurs due to friction between the particles of the fluid itself, kinematic viscosity, and also the friction of the liquid with the internal wall of the pipe (MIRANDA, 2016). It can be estimated through several equations (PIMENTA et al., 2018), allowing the designer to choose which head loss equation to use, provided that the situation meets the assumptions of use. Inadequate choice can lead to significant errors in the definition of pipe diameter and, consequently, throughout the hydraulic structure of the project (SOUSA, 2018).

Among the head loss equations applied to pressurized pipes, the Darcy-Weisbach equation can be applied under any condition of velocity, temperature, roughness and Reynolds number (ALLEN, 1999; LI et al., 2017), being considered the most complete and, because of this, the most recommended equation (LAPERUTA NETO et al., 2011; GEISENHOFF, 2018; MELO et al., 2019; MINHONI et al., 2020). On the other hand, calculating continuous head loss with the Darcy-Weisbach equation is relatively difficult, since it involves separately the calculation of the friction factor, which is not considered to be simple (VON BERNUTH, 1990; JAMIL et al., 2020).

For mathematical simplicity, many designers use empirical equations such as those of Hazen-Williams, Manning and Scobey to determine continuous head losses rather than the theoretical equation of DarcyWeisbach (ALAZBA et al., 2012; RETTORE NETO et al., 2009). However, studies have found that the Scobey equation applied to diameters below $50 \mathrm{~mm}$ generates percentage errors greater than $20 \%$ in the head loss estimate (RETTORE NETO, 2016).

Therefore, the present study aims to develop a simplified formula from the modification of the Scobey equation, to determine head loss in PVC pipes with nominal diameters from 32 to $200 \mathrm{~mm}$, comparing its performance with the results obtained by the Darcy-Weisbach equation.

\section{MATERIAL AND METHODS}

Head loss determination was simulated using Microsoft Excel ${ }^{\circledR} 2016$ software, for a PVC (polyvinyl chloride) main line with 1000 meters length, for nominal diameters of 32 , $40,50,75,100,125,150$ and $200 \mathrm{~mm}$, with inner diameters of $28.81,35.3,48.1,72.5$, 97.6, 120, 144 and $200 \mathrm{~mm}$, respectively, with flow velocity ranging from $0.5 \mathrm{~m} \mathrm{~s}-1$ to $3.5 \mathrm{~m}$ $\mathrm{s}-1$ at intervals of $0.1 \mathrm{~m} \mathrm{~s}-1$. For equivalent materials, the literature reports broad ranges representative of the values that can be assumed by the absolute roughness. Table 1 indicates some values and intervals of absolute roughness in PVC pipes found in the technical literature and used in the simulation.

Table 1: Reference values of absolute roughness for PVC pipes, according to different authors.

\begin{tabular}{ll}
\hline Absolute roughness $-\varepsilon(\mathrm{mm})$ & Source \\
\hline 0.020 & SOUZA et al., 2014 \\
0.015 & ALZBA, 2012 \\
0.006 & BEZZERA et al., 2017 \\
0.00531 & KELLNER et al., 2016
\end{tabular}


0.003334

0.002

0.0015
ROCHA et al., 2017

ALLEN, 1999

URIBE et al., 2015
Continuous head loss was simulated by the Darcy-Weisbach equation (Equation 01), with friction factor (f) determined by the Colebrook-White formula (Equation 02), varying the roughness coefficient according to the values presented in Table 1. Subsequently, the continuous head loss determined by the Darcy-Weisbach equation was used to find a new "Ks" Scobey coefficient (Equation 03 and
04) for each diameter studied. Then, the new Ks values were correlated with the flow velocity, obtaining a new function (Equation $05)$ and later incorporated into the Scobey equation (Equations 06, 07 and 08). Table 2 shows the equations for determining head loss and the new value of the Ks coefficient used in the modification of the Scobey equation.

Table 2. Equations used to simplify Scobey's empirical equation.

Eq. No.

01

02

04

05

06

08
Nomenclature

Darcy-Weisbach

Colebrook-White

Scobey

KS (NEW)

KS (NEW)

Simplified formula

Simplified formula

Simplified formula
Equations

$$
\begin{aligned}
& \mathrm{HF}_{\mathrm{DW}}=\mathrm{f} \frac{\mathrm{L}}{\mathrm{D}} \frac{\mathrm{V}^{2}}{2 \mathrm{~g}} \\
& \left(\frac{1}{\sqrt{\mathrm{f}}}=-2 \log \left(\frac{\varepsilon}{3.7 \mathrm{D}}+\frac{2.51}{\operatorname{Re} \sqrt{\mathrm{f}}}\right)\right.
\end{aligned}
$$

$$
\mathrm{HF}_{(\mathrm{SCOBEY})}=\frac{\mathrm{K}_{\mathrm{S}}}{387} \frac{\mathrm{L}}{\mathrm{D}^{1.1}} \mathrm{~V}^{1.9}
$$$$
\mathrm{K}_{\mathrm{S}(\mathrm{NEW})}=\frac{\mathrm{HF}_{(\mathrm{DARCY})}}{\frac{\mathrm{L}}{\mathrm{D}^{1.1}} \mathrm{~V}^{1.9}} 387
$$$$
\mathrm{K}_{\mathrm{S}(\mathrm{NEW})}=\alpha \cdot \mathrm{V}^{\beta}
$$

$$
\mathrm{HF}_{(\mathrm{SF})}=\frac{\alpha \mathrm{V}^{\beta}}{387} \frac{\mathrm{L}}{\mathrm{D}^{1.1}} \mathrm{~V}^{1.9}
$$

$$
\mathrm{HF}_{(\mathrm{SF})}=\frac{\alpha \mathrm{V}^{\beta+1.9}}{387} \frac{\mathrm{L}}{\mathrm{D}^{1.1}}
$$

$$
\mathrm{HF}_{(\mathrm{SF})}=\frac{\left(\alpha \mathrm{D}^{\beta+1.1}\right)\left(\mathrm{V}^{\beta+1.9}\right)}{387} \mathrm{~L}
$$

HF - head loss (m.w.c.); D - inner pipe diameter (m); f - friction factor of Darcy-Weisbach equation (dimensionless); L - pipe length (m); V - flow velocity $\left(\mathrm{m} \mathrm{s}^{-1}\right) ; \varepsilon$ - roughness coefficient (m); Re - Reynolds number (dimensionless); $\mathrm{g}-$ gravity acceleration $\left(\mathrm{m} \mathrm{s}^{-2}\right) ; \mathrm{K}_{\mathrm{S}}-$ coefficient of the Scobey equation (dimensionless); $\mathrm{HF}_{(\mathrm{SF})}-$ head loss by the simplified Scobey formula (m.w.c.); a, b - calibration coefficients of the equation (dimensionless). 
To verify the performance of the new equation, the head loss values calculated by the Darcy-Weisbach equation (reference head loss) were compared with the data obtained using the simplified Scobey equation (Equation 08). These results were statistically evaluated using 1:1 line, Willmott's index of agreement (d), correlation coefficient (r) and performance index (Id), according to equations 09,10 and 11 , respectively, which are presented in Table 3.

Moreover, the percentage error (Equation 12) was adopted to evaluate head loss as a function of flow velocity (SOUZA, 2018).

The parameters used for classifying the agreement index, precision index and performance index are presented in Table 4.

Table 3. Statistical parameters used in the study.
Eq. No.
Abbreviation
Equation

9

d

10

r

11

Id

Error $(\%)$

12

$$
\begin{gathered}
1-\left[\frac{\sum_{i=1}^{n}\left(P_{i}-O_{i}\right)^{2}}{\sum_{i=1}^{n}\left(\left|P_{i}-O_{i}\right|+\left|O_{i}-O\right|\right)^{2}}\right] \\
\frac{\sum_{i=1}^{n}\left(P_{i}-P\right)\left(O_{i}-0\right)}{\sqrt{\sum_{i=1}^{n}\left(P_{i}-P\right)^{2} \sum_{i=1}^{n}\left(O_{i}-0\right)^{2}}}
\end{gathered}
$$

r.d

$\operatorname{Error}(\%)=\frac{|\mathrm{TV}-\mathrm{AV}|}{\mathrm{AV}} 100$

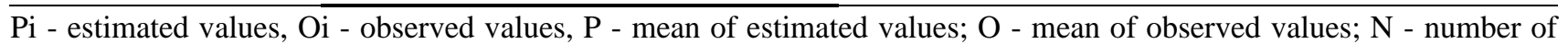
observations; $h f_{\text {est. }}$ - Head loss estimated by the simplified formula; $h f_{\text {ref.- }}$ Reference head loss by Darcy-Weisbach equation; Error (\%) - percentage error; TV - theoretical value (obtained by simplified equation), AV - actual value (obtained by Darcy-Weisbach equation).

Table 4. Criteria for interpretation of the Agreement Index, Correlation Coefficient and Performance Index and their respective classifications.

\begin{tabular}{lrrl}
\hline Agreement Index $(\mathrm{d})$ & \multicolumn{1}{l}{$\begin{array}{l}\text { Correlation } \\
\text { Coefficient }(\mathrm{r})\end{array}$} & $\begin{array}{l}\text { Performance } \\
\text { Index (Id) }\end{array}$ & Classification \\
\hline $0.95-1.00$ & $0.95-1.00$ & $0.90-1.00$ & Excellent \\
$0.89-0.95$ & $0.89-0.95$ & $0.80-0.90$ & Great \\
$0.84-0.89$ & $0.84-0.89$ & $0.70-0.80$ & Very Good \\
$0.77-0.84$ & $0.77-0.84$ & $0.60-0.70$ & Good \\
$0.71-0.77$ & $0.71-0.77$ & $0.50-0.60$ & Moderately Good \\
$0.63-0.71$ & $0.63-0.71$ & $0.40-0.50$ & Moderate
\end{tabular}


Simplified Scobey formula for determining head loss in pressurized pipes

$\begin{array}{llll}0.55-0.63 & 0.55-0.63 & 0.30-0.40 & \text { Moderately Poor } \\ 0.45-0.55 & 0.45-0.55 & 0.20-0.30 & \text { Poor } \\ 0.32-0.45 & 0.32-0.45 & 0.10-0.20 & \text { Very Poor } \\ 0.00-0.32 & 0.00-0.32 & 0.00-0.10 & \text { Terrible }\end{array}$

Source: Pimenta et al. (2018)

\section{RESULTS AND DISCUSSION}

The head loss values obtained by DarcyWeisbach equation (reference head loss) were compared with the data obtained by the original (Equation 03) and modified (Equation 14) Scobey equations with coefficient of the original Scobey equation (Ks) fixed at 0.32 (recommended for PVC pipes). The results of head loss estimated by the original and modified Scobey equations are shown in Figure 1. It can be noted that both equations showed good adherence to the 1:1 line, because the values obtained by the Scobey equation are very close to the results estimated by the Darcy-Weisbach equation, using the same variables.

The simplified Scobey equation had coefficient of determination $\left(\mathrm{R}^{2}\right)$ equal to 0.996, which was higher than the coefficient obtained by the original Scobey equation, indicating an excellent proportion that the variation of the response variable is explained by the variation of the predictor variable (KENNEDY, 2008).

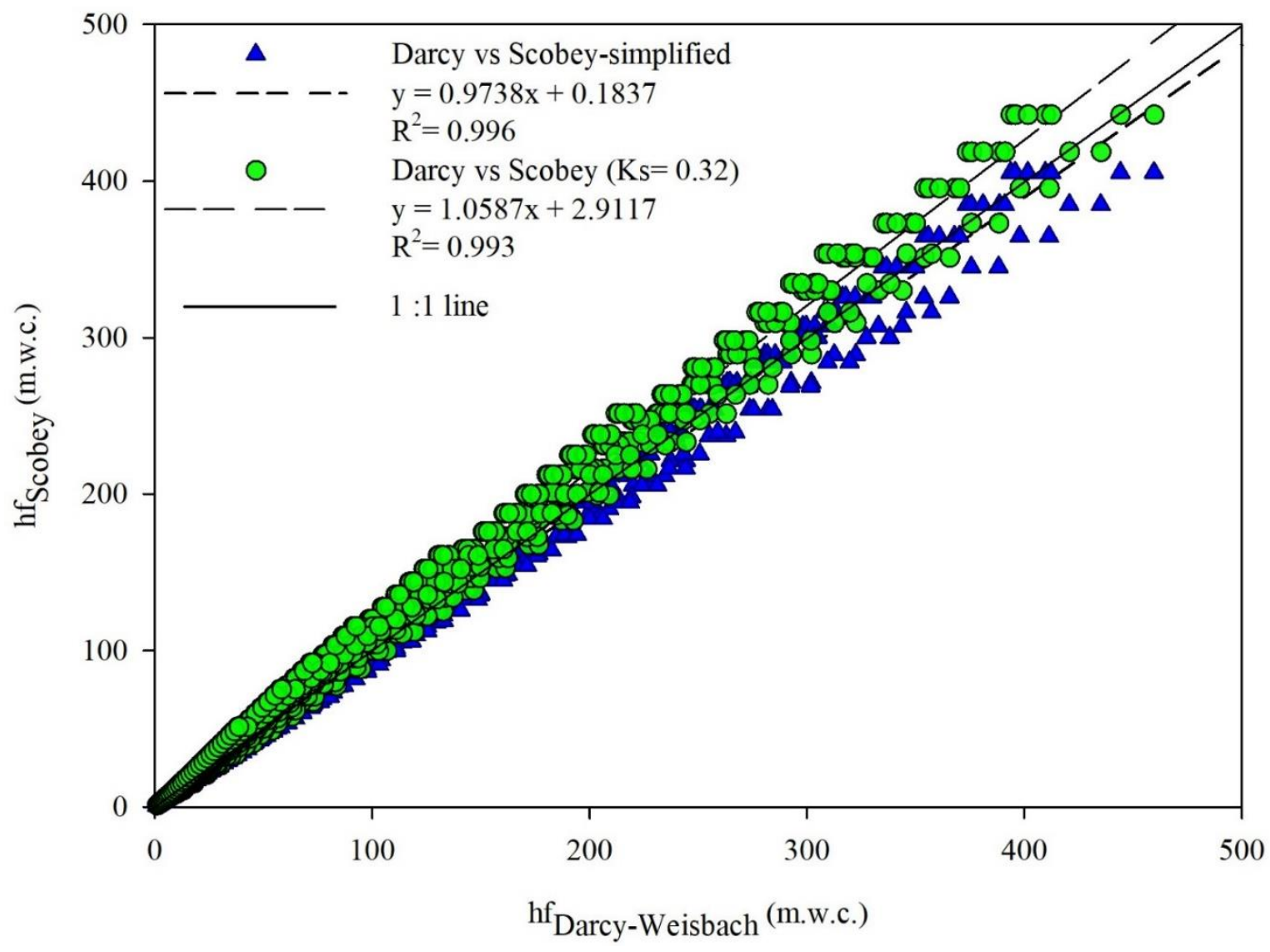

Figure 1. Comparison of continuous head loss (hf) estimated by the Scobey equation (original and simplified) and the Darcy-Weisbach equation, based on the simulations performed in a main line with 1000 meters length for the different values of roughness, inner diameter of the pipes and flow velocity. 
Figure 1 shows that the highest values of energy loss estimated by the empirical Scobey equation were also the ones with the most dispersion compared to the results obtained by the Darcy-Weisbach equation (reference).

This distance of the data from the 1:1 line is due to the unsatisfactory performance of the empirical equation of Scobey in situations of pipes with nominal diameters greater than $100 \mathrm{~mm}$ (SOUSA, 2018). Table 5 shows the Willmott's index of agreement (d), correlation coefficient (r) and performance index $(\mathrm{P})$, to compare the results obtained by the Darcy-Weisbach equation (reference values) and by the simplified Scobey equation (estimated values), for different diameters and internal wall roughness of the pipes.

Table 5. Statistics of the data obtained by comparing the simplified Scobey equation and the DarcyWeisbach formula.

\begin{tabular}{|c|c|c|c|c|}
\hline \multirow{2}{*}{$\begin{array}{l}\text { Pipe } \\
(\mathrm{mm})\end{array}$} & \multirow{2}{*}{$\begin{array}{l}\text { Roughness } \\
(\mathrm{mm})\end{array}$} & \multicolumn{3}{|c|}{ Statistical indices } \\
\hline & & $\mathrm{d}$ & $\mathrm{r}$ & $\mathrm{P}$ \\
\hline \multirow{7}{*}{32} & 0.0015 & 0.998 & 0.991 & 0.988 \\
\hline & 0.002 & 0.998 & 0.991 & 0.989 \\
\hline & 0.003334 & 1.000 & 0.991 & 0.990 \\
\hline & 0.00531 & 1.000 & 0.991 & 0.991 \\
\hline & 0.006 & 1.000 & 0.991 & 0.990 \\
\hline & 0.015 & 0.986 & 0.991 & 0.977 \\
\hline & 0.02 & 0.975 & 0.991 & 0.966 \\
\hline \multirow{7}{*}{40} & 0.0015 & 0.998 & 1.000 & 0.998 \\
\hline & 0.002 & 0.998 & 1.000 & 0.998 \\
\hline & 0.003334 & 1.000 & 1.000 & 1.000 \\
\hline & 0.00531 & 1.000 & 1.000 & 1.000 \\
\hline & 0.006 & 1.000 & 1.000 & 1.000 \\
\hline & 0.015 & 0.977 & 1.000 & 0.977 \\
\hline & 0.02 & 0.976 & 1.000 & 0.976 \\
\hline \multirow{7}{*}{50} & 0.0015 & 0.998 & 1.000 & 0.998 \\
\hline & 0.002 & 0.999 & 1.000 & 0.999 \\
\hline & 0.003334 & 1.000 & 1.000 & 1.000 \\
\hline & 0.00531 & 1.000 & 1.000 & 1.000 \\
\hline & 0.006 & 0.999 & 1.000 & 0.999 \\
\hline & 0.015 & 0.978 & 1.000 & 0.978 \\
\hline & 0.02 & 0.975 & 1.000 & 0.974 \\
\hline \multirow{2}{*}{75} & 0.0015 & 0.999 & 1.000 & 0.999 \\
\hline & 0.002 & 1.000 & 1.000 & 1.000 \\
\hline
\end{tabular}


Simplified Scobey formula for determining head loss in pressurized pipes

\begin{tabular}{|c|c|c|c|c|}
\hline & 0.003334 & 1.000 & 1.000 & 1.000 \\
\hline & 0.00531 & 0.999 & 1.000 & 0.999 \\
\hline & 0.006 & 0.999 & 1.000 & 0.999 \\
\hline & 0.015 & 0.978 & 1.000 & 0.977 \\
\hline & 0.02 & 0.977 & 1.000 & 0.977 \\
\hline \multirow{7}{*}{100} & 0.0015 & 1.000 & 1.000 & 1.000 \\
\hline & 0.002 & 1.000 & 1.000 & 1.000 \\
\hline & 0.003334 & 1.000 & 1.000 & 1.000 \\
\hline & 0.00531 & 0.998 & 1.000 & 0.998 \\
\hline & 0.006 & 0.998 & 1.000 & 0.998 \\
\hline & 0.015 & 0.985 & 1.000 & 0.985 \\
\hline & 0.02 & 0.977 & 1.000 & 0.977 \\
\hline \multirow{7}{*}{125} & 0.0015 & 1.000 & 1.000 & 1.000 \\
\hline & 0.002 & 1.000 & 1.000 & 1.000 \\
\hline & 0.003334 & 0.999 & 1.000 & 0.999 \\
\hline & 0.00531 & 0.998 & 1.000 & 0.998 \\
\hline & 0.006 & 0.997 & 1.000 & 0.997 \\
\hline & 0.015 & 0.976 & 1.000 & 0.975 \\
\hline & 0.02 & 0.975 & 1.000 & 0.975 \\
\hline \multirow{7}{*}{150} & 0.0015 & 1.000 & 1.000 & 1.000 \\
\hline & 0.002 & 1.000 & 1.000 & 0.999 \\
\hline & 0.003334 & 0.999 & 1.000 & 0.999 \\
\hline & 0.00531 & 0.997 & 1.000 & 0.997 \\
\hline & 0.006 & 0.996 & 1.000 & 0.996 \\
\hline & 0.015 & 0.974 & 1.000 & 0.974 \\
\hline & 0.02 & 0.974 & 1.000 & 0.974 \\
\hline \multirow{7}{*}{200} & 0.0015 & 0.998 & 1.000 & 0.998 \\
\hline & 0.002 & 0.998 & 1.000 & 0.998 \\
\hline & 0.003334 & 0.997 & 1.000 & 0.997 \\
\hline & 0.00531 & 0.994 & 1.000 & 0.994 \\
\hline & 0.006 & 0.993 & 1.000 & 0.993 \\
\hline & 0.015 & 0.971 & 1.000 & 0.971 \\
\hline & 0.02 & 0.971 & 1.000 & 0.971 \\
\hline
\end{tabular}


The comparison between the values of head loss by the simplified equation and the Universal equation (Darcy-Weisbach), for pipes with the respective values of diameter and roughness (Table 5), showed high agreement, high degree of correlation and Performance Index considered as "Excellent" (PIMENTA et al., 2018).
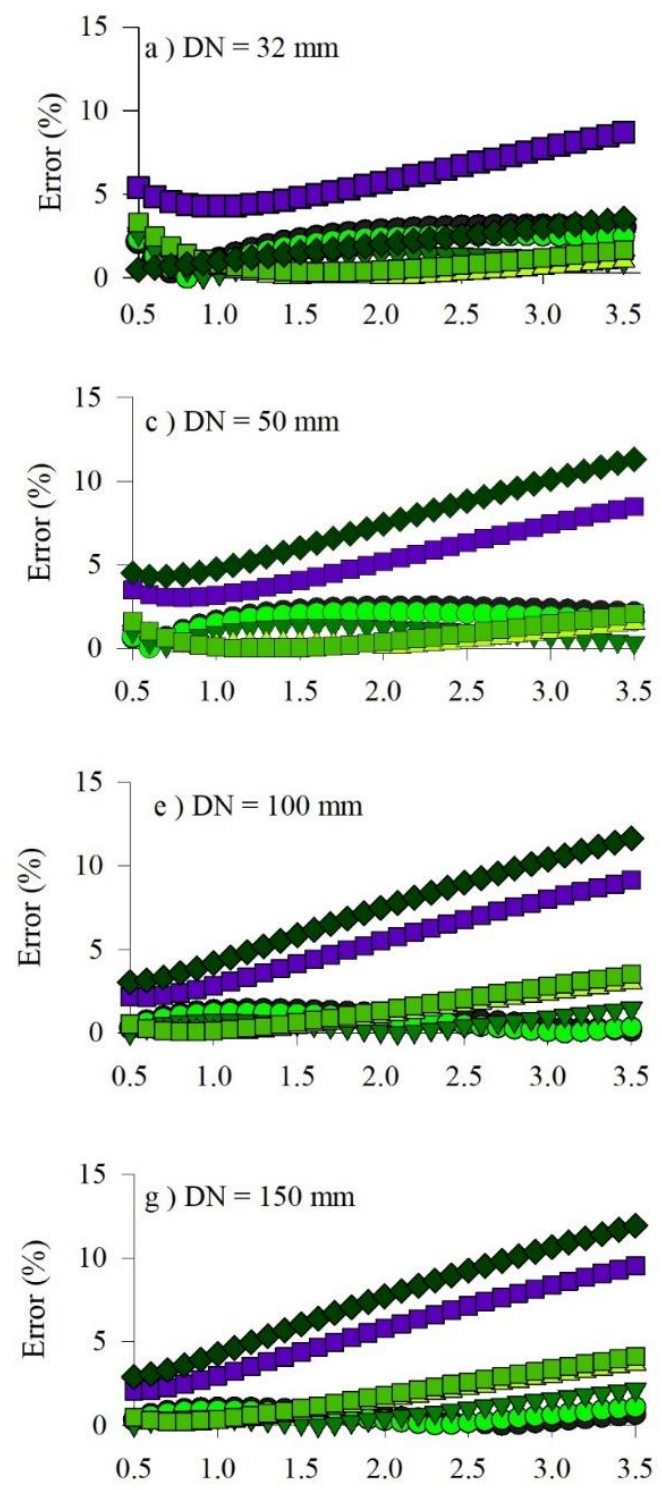

Flow velocity $\left(\mathrm{m} \mathrm{s}^{-1}\right)$

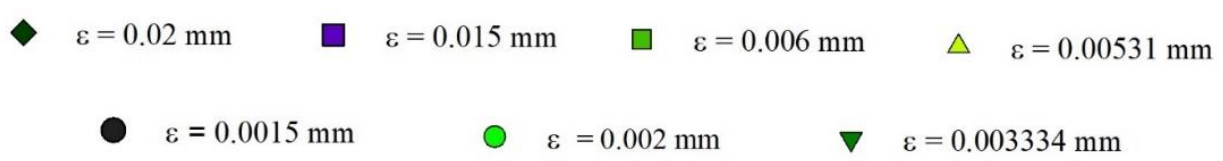

Figure 2. Percentage errors between the values of continuous head loss obtained by the Scobey equation and by the Darcy-Weisbach formula.

For better interpretation of the simulations performed, the percentage error was used to demonstrate the values of head loss obtained with the simplified equation for the flow velocities ranging from 0 to $3.5 \mathrm{~m} \mathrm{~s}$ 1 , for each value of diameter and roughness under study (Figure 2).
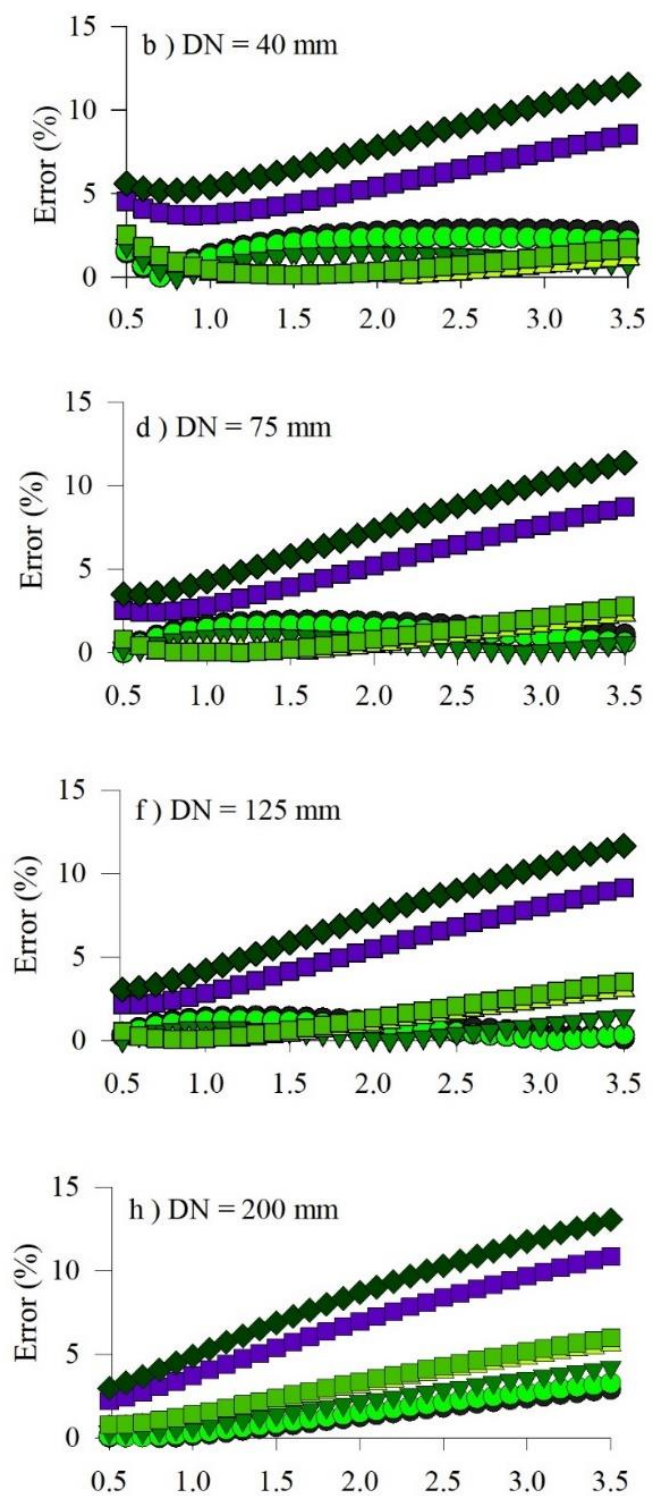

Flow velocity $\left(\mathrm{m} \mathrm{s}^{-1}\right)$ 
Figure 2 shows that the percentage errors decrease with the reduction in the internal roughness of the pipe. Since there is no perfectly smooth inner surface in pipes (MACDONALD et al., 2016), their internal walls usually have some degree of roughness. However, with the improvement of production processes, imperfections on these walls are minimized.

The calculation of head loss with the simplified equation led to lower percentage errors compared to the original Scobey equation. According to Sousa (2018), who evaluated the error in estimating continuous head loss in PVC and polyethylene pipes, the Scobey equation overestimated head loss in pipes of 100 and $200 \mathrm{~mm}$ in diameter by more than $30 \%$, compared to the Universal formula.

Therefore, the proposed equation showed satisfactory results when compared to the results obtained with the Universal formula. In addition, empirical equations have specific coefficients that become useful almost exclusively for academic purposes and have little practicality. In this context, the use of equations with few variables and good results compared to complex equations is more useful in comparison with the other ones and the best option for the designer (YURDEM et al., 2010).

\section{Equation}

The equation below (Equation 14) was obtained from the simulations performed and shows application for calculating head loss in PVC pipes with nominal diameters of 35,50 , $75,100,125,150$ and $200 \mathrm{~mm}$, simplifying the determination of head loss with excellent precision.

$$
\mathrm{HF}_{(\text {SIMPLIFIED SCOBEY })}=\frac{\left(0.2149 \mathrm{D}^{-1.223}\right)\left(\mathrm{V}^{1.8}\right)}{387} \mathrm{~L}
$$

\section{CONCLUSIONS}

It can be concluded that the simplification of Scobey showed good performance for the calculation of head loss in polyvinyl chloride pipes with nominal diameters of $32,40,50,75,100,125,150$ and 200 millimeters, with percentage errors below $6 \%$, compared to the Darcy-Weisbach equation, for pipes with relative roughness between 0.006 and 0.0015 millimeters.

\section{REFERENCES}

ALAZBA, A. A.; MATTAR, M.A.; ELNESR, M.N.; AMIN, M.T. Field assessment of friction head loss and friction correction factor equations. Journal of Irrigation and Drainage Engineering, v. 167, n. 2, p. 166176, 2012. https://doi.org/10.1061/(ASCE)IR.19434774.0000387

ALLEN, R. G. Relating the Hazen-Williams and Darcy-Weisbach friction loss equations for pressurized irrigation. American Society of Agricultural Engineers. v. 12, n. 6, p. 685693, 1999. DOI: $10.13031 / 2013.25699$

ALVES, É. DA SILVA; SAAD, J. C. C.; SCHIMIDT, A. P. R. A.; ARAÚJO, L. M.; GOMES, M. D. DE A.; SANTOS, J. É. O. Caracterização de sistema de irrigação por aspersão convencional dimensionado com vazão econômica e prática e diferentes configurações hidráulicas. Revista Brasileira de Agricultura Irrigada. v. 11, n. 8, p. 21722182, 2017. DOI: 10.7127/rbai.v11n800706

BEZERRA, A. A.; CASTRO, M. A. H.; ARAÚJO, R. S. A. Absolute roughness calculation by the friction factor calibration using the Alternative Hydraulic Gradient Iterative Method on water distribution networks. Revista Brasileira de Recursos Hídricos. v. 22, n. 24, p. 01-11. 2017. https://doi.org/10.1590/23180331.021720160018

GEISENHOFF, L. O.; FLORES, D. M.; FILHO, R. R. G.; SANTOS, R. C.; JORDAN, R. A.; DE OLIVEIRA, L. C. IRRIGAR Aplicativo computacional para o 
dimensionamento econômico de sistemas de irrigação por aspersão convencional. Revista Brasileira de Agricultura Irrigada. v. 12, n. 4, p. 2761-2775, 2018. DOI: 10.7127/rbai.v12n400972

JAMIL, R.; M. MUJEEBU, M. A. Empirical Relation between Hazen-Williams and DarcyWeisbach Equations for Cold and Hot Water Flow in Plastic Pipes. WATER, v. 10, n. 2 p. 104-114,

2019.

DOI:10.14294/WATER.2019.1

KELLNER, E.; AKUTSU, J.; REIS, L. F. R. Avaliação da rugosidade relativa dos tubos de PVC com vistas ao dimensionamento das redes de distribuição de água. Revista Engenharia Sanitária e Ambiental. v. 21, n. 2, p. 347-355, 2016. https://doi.org/10.1590/S1413-

41522016141081

KENNEDY, P. A. Guide to Econometrics. 6. ed. Massachusetts: Blackwell Publishing, 2008.585 p.

LI, T.; LIANG, C.; ZHANG, Y.; ZHAO, P. Comparison and validation of the ratio of Manning coefficient to flow depth for soil erosion prediction using published data with different external impacts. Journal of Soils and Sediments. v. 17, n. 6, p. 1682-1695, 2017. DOI 10.1007/s11368-016-1645-5

MACDONALD, M.; CHAN, L.; CHUNG, D.; HUTCHINS, N.; OOI, A. Turbulent flow over transitionally rough surfaces with varying roughness densities. Journal of Fluid Mechanics. v. 804, p. 130-161, 2016. https://doi.org/10.1017/jfm.2016.459

MELO, V. G. M. L.; FRIZZONE, J. A.; CAMARGO, A. P.; BOMBARDELLI, W. W. Á. Head loss in laser-perforated thin-walled polyethylene pipes for irrigation. Revista Brasileira de Engenharia Agrícola e Ambiental, v. 23, n. 5, p. 317-323, 2019. https://doi.org/10.1590/1807-

1929/agriambi.v23n5p317-323
MINHONI, R. T. A.; PEREIRA, F. F. S.; DA SILVA, T. B. G.; CASTRO, E. R.; SAAD, J. C. C. The performance of explicit formulas for determining the darcy-weisbach friction factor. Engenharia Agrícola, v. 40, n. 2, p. 258-265, 2020. https://doi.org/10.1590/18094430-Eng.Agric.v40n2p258-265/2020

MIRANDA, E. P.; CUSTODIO, T. B. DE S.; LIMA, F. U.; PEREIRA, T. A.; BICUDO, A. L. R. Ajuste da equação de Hazen-Willians para determinação da perda de carga contínua em tubulações de PVC. Irriga, v. 1, n. 1, p. 94-100, 2019.

DOI:10.15809/irriga.2019v1n1p94-100

MIRANDA, E. P. Programa computacional para dimensionamento e determinação dos custos de energia elétrica de um sistema de irrigação localizada. $250 \mathrm{f}$. Tese (Doutorado em Agronomia), Universidade Estadual Paulista, Faculdade de Ciências Agronômicas, Botucatu, São Paulo, SP, 2016. https://repositorio.unesp.br/handle/11449/1395 30

LAPERUTA NETO, J.; CRUZ, R. L.; FILHO, J. L.; PLETSCH, T. A. Perda de carga em mangueiras gotejadoras novas e usadas. Irriga, v. 16, n. 3, p. 329-338, 2011. http://dx.doi.org/10.15809/irriga.2011v16n3p3 29

PIMENTA, B. D.; ROBAINA, A. D.; PEITER, M. X.; PEREIRA A. C.; RODRIGUES, S. A.; LOREGIAN, M.V. Desempenho e precisão de equações explícitas do coeficiente de perda de carga em regime de fluxo. Revista Brasileira de Agricultura Irrigada, v. 12, n. 2, p. 2443-2453, 2018. DOI:10.7127/rbai.v12n200743

RETTORE NETO, O.; DE MIRANDA, J. H.; FRIZZONE, J. A.; WORKMAN, S. R. Local head loss of non-coaxial emitters inserted in polyethylene pipe. American Society of Agricultural and Biological Engineers, v. 52, n. 3, p. 729-738, 2009. https://doi.org/10.13031/2013.27394RETTOR E NETO, O.; TAVARES, V. E. Q.; FARIA, 
L. C.; KOPP, L. M.; TIMM, L. C. Comportamento das equações de Scobey, Manning e Fair-Whipple-Hsiao quando utilizadas para estimativa da perda de carga em tubos com comportamento elástico. Revista Brasileira de Agricultura Irrigada, v. $10, \quad$ n. $1, \quad$ p. 420-427, 2016. DOI:10.7127/rbai.v10n100343

ROCHA, H. S.; MARQUES, P. A. A.; CAMARGO, A. P.; FRIZZONE, J. A.; SARETTA, E. Internal surface roughness of plastic pipes for irrigation. Revista Brasileira de Engenharia Agrícola e Ambiental, v. 21, n. $3, \quad$ p. 143-149, 2017. https://doi.org/10.1590/1807-

1929/agriambi.v21n3p143-149

SOUSA, J. S. C.; NETO, J. D. Equação explícita para cálculo do fator de atrito de Darcy-Weisbach em projetos de irrigação pressurizada. Brazilian Journal of Irrigation and Drainage, v. 19, n. 1, p. 137-148, 2014

SOUSA, J. S. C. Equações de perda de carga para dimensionamentos hidráulicos em projetos de irrigação pressurizada. Revista Brasileira de Agricultura Irrigada, v. 12, n. 7, p. 3159-3168, 2018. DOI:10.7127/rbai.v.12n7001041
URIBE, J.; SALDARRIAGA, J.; PÁEZ, D. Effects of the Use of Hazen-Williams Equation on large WDS's Planning Models. In: WORLD ENVIRONMENTAL AND WATER RESOURCES CONGRESS: FLOODS, DROUGHTS, AND ECOSYSTEMS, 2015, Austin. Anais Eletrônicos... Recife: ASCE, 2015. Disponível em: $<$ https://ascelibrary.org/doi/10.1061/97807844 79162.083>

VON BERNUTH, R. D. Simple and accurate friction loss equation for plastic pipe. Journal of Irrigation and Drainage Engineering. v. 116, n. 2, p. 294-298, 1990. https://doi.org/10.1061/(ASCE)07339437(1990)116:2(294)

YURDEM, $\quad$ H.; $\quad$ DEMIR, $\quad$ V.; DEGIRMENCIOGLU, A. Development of a mathematical model to predict clean water head losses in hydrocyclone filters in drip irrigation systems using dimensional analysis. Biosystems Engineering, v. 105, n. 4, p. 495506, 2010. https://doi.org/10.1016/j.biosystemseng.2010. 02.001 